\title{
Quality Assurance (QA) Dan Quality Control (QC) Pada Instrumen Radioterapi Pesawat LINAC
}

\author{
Bambang Haris Suharmono $^{1}$, Ika Yuni Anggraini*' ${ }^{*}$, Hilmaniyya², Suryani Dyah Astuti² \\ ${ }^{1}$ Instalasi Radiologi, Rumah Sakit Dr. Sutomo, Surabaya \\ ${ }^{2}$ Jurusan Fisika, Departemen Fisika Fakultas Sains dan Teknologi Universitas Airlangga, \\ Surabaya \\ 1 e-mail :bambangharis26@yahoo.com, \\ 1 e-mail: ka.yuni.anggraini-2017@fst.unair.ac.id, \\ 2e-mail: hilmaniyya-2017@fst.unair.ac.id, \\ 2 e-mail: suryanidyah@fst.unair.ac.id
}

\begin{abstract}
LINAC is a radiotherapy instrument used to kill tumor and cancer cells in patients. To guarantee the quality of LINAC instruments, QA (Quality Assurance) is needed and to prove the quality assurance there is a need for QC (Quality Control). This is done also aims to examine and test data to determine standards and check the suitability of products to achieve maximum manufacturing operations or measures taken, namely to assess, maintain or improve the quality of treatment given. The role of medical physicists is very important because only medical physicists carry out the implementation of quality assurance of radiotherapy instruments.
\end{abstract}

Keywords: Radiotherapy, Linear Accelerator, Quality Assurance, Quality Control

\begin{abstract}
Abstrak
LINAC adalah instrumen radioterapi yang digunakan untuk mematikan sel tumor maupun kanker pada pasien. Untuk menjamin kualitas instrumen LINAC, maka diperlukan QA (Quality Assurance) dan untuk membuktikan adanya jaminan kualitas perlu QC (Quality Control). Hal ini dilakukan juga bertujuan untuk memeriksa dan menguji data untuk menentukan standar dan mengecek kesesuaian produk mencapai operasi manufaktur yang maksimum atau ukuran yang diambil yaitu untuk menilai, merawat atau memperbaiki kualitas perlakuan yang diberikan. Peran fisikawan medis sangat penting karena hanya fisikawan medis yang menjalankan pelaksanaan jaminan kualitas instrumen radioterapi.
\end{abstract}

Kata kunci: Radioterapi, Linear Accelerator, Quality Assurance, Quality Control

\section{PENDAHULUAN}

Tumor dan kanker merupakan salah satu penyakit yang memiliki resiko kematian yang cukup tinggi pada penderitanya. Pada zaman sekarang sangat banyak ditemukan pendderita penyakit kanker yang disebabkan pola makan yang tidak bagus, akibat terpapr radiasi yang melampaui dosis ambang maupun penyakit keturunan. Dalam pengobatannya, biasanya dilakukan surgery(operasi pengangkatan sel tumor), kemoterapi(terapi dengan menggunakan obat-obatan) atau dengan terapi radiasi. Namun dalam pengobataan surgery maupun kemoterapi biasanya sel tumor maupun kanker akan ditemukan tumbuh kembali. Oleh karena iitu sanngat dianjurkan pada pasien kanker untuk melakukan terapi radiasi untuk membunuh sel tumor/kanker yang dimungkinkan masih ada di dalam tubuh pasien tersebut.

LINAC adalah salah satu instrumen radioterapi yang digunakan untuk mematikan sel tumor maupun kanker pada pasien. Sehingga untuk menjamin kualitas instrumen LINAC, maka diperlukan QA (Quality Assurance) dan untuk membuktikan adanya jaminan kualitas perlu QC (Quality Control). Hal ini juga dilakukan dengan tujuan untuk memeriksa dan menguji data untuk menentukan standar dan mengecek kesesuaian produk mencapai operasi manufaktur yang maksimum atau ukuran yang diambil yaitu untuk menilai, merawat atau memperbaiki kualitas perlakuan yang diberikan. Peran fisikawan medis sangat penting karena hanya fisikawan medis yang menjalankan pelaksanaan jaminan kualitas instrumen radioterapi.

Dalam program $\mathrm{QA} / \mathrm{QC}$ seluruh pihak yang melakukan kegiatan QA/QC instrumen radioterapi harus mengetahui protokol-protokolnya. Semua pihak yang terkait dengan kegitan tersebut memiliki tanggung jawab sepenuhnya dan apabila terdapat hasil yang tidak sesuai dengan parameter yang digunakan atau ditemukan adanya kerusakan pada instrumen radioterapi maupun pada beberapa perangkat yang diperlukan untuk radioterapi misalkan perangkat keamanan maka kerusakan harus segera diperbaiki. Hasil dari kegitan QA/QC 
perlu didokumentasikan sebagai pengecekan kulaitas kinerja instrumen. Dalam bidang radioterapi, fisikawan medis berperan penting dalam kegiatan QA/QC ini. Selain itu, fisikawan medis juga berperan dalam Treatment Planning System (TPS) yaitu mengolah data berkas yang akan diberikan pada pasien dan kalkulasi hasil planning untuk pasien radioterapi (terapi radiasi eksternal maupun terapi radiasi internal).

\section{RADIASI}

Radiasi adalah pancaran energi dari dalam atom, radiasi dapat berupa partikel atau gelombang (BATAN,2019). Radiasi dalam bentuk partikel atau korpuskuler merupakan radiasi yang berasal dari partikel seperti partikel alfa dan beta. Sedangkan radiasi gelombang elektromagnetik seperti sinar gamma, sinar $\mathrm{X}$ dan lain-lalin merupakan radiasi yang tidak memiliki massa dan muatan listrik.

Secara garis besar radiasi dibagi menjadi 2 yaitu radiasi pengion dan radiasi non pengion. Radiasi pengion yaitu jenis radiasi yang dapat menyebabkan proses ionisasi apabila berinteraksi dengan materi. Jenis radiasi pengion antara lain: partikel alpha, partikel beta, sinar gamma, sinar-X dan neutron. Menurut sifat kejadiannya radiasi pengion ini dibagi menjadi dua yaitu raiasi langsung dan radiasi tak langsung. Sedangkan radiasi nonpengion yaitu jenis radiasi yang tidak akan menyebabkan efek ionisasi apabila berinteraksi dengan materi. Jenis radiasi non-pengion antara lain: gelombang radio (yang membawa informasi dan hiburan melalui radio dan televisi), gelombang mikro (yang digunakan dalam microwave oven dan transmisi seluler handphone), sinar inframerah (yang memberikan energi dalam bentuk panas).

\subsection{Radioterapi}

Radioterapi adalah salah satu pemanfaatan radiasi delam bidang medis yang merupakan teknik pengobatan penyakit seperti kanker dan tomur dengan menggunakan sinar pengion. Teknik pengobatan ini mulai digunakn sebagai salah satu regimen pengobatan tumor ganas pada akhir abad ke19 segera setelah ditemukannya sinar-X oleh W.C. Rontgen, sifat-sifat radioaktivitas oleh Becquerel dan radium oleh Pierre dan Merrie Curie. Seiring berjalannya waktu dan perkembangan teknologi yang semakin pesat, teknik radioterapi terus mengalami perbaikan sehingga pengobatan dengan teknik ini digunakan kembali dan semakin diminati terutama untuk pengobatan kanker.

Jenis radioterapi dibagi menjadi dua yaitu radiasi eksternal dan radiasi internal. Radiasi eksternal merupakan pengobatan radiasi dengan sumber radiasi yang mempunyai jarak jauh sumber radiasi berada jauh dari target dengan kata lain sumber radiasi berada di luar tubuh. Pada radiasi jenis ini terdapat dua jenis pesawat yang dapat digunakan yaitu pesawat Cobalt60 dan pesawat LINAC yang pada dasarnya prinsip penggunaan dari kedua pesawat tersebut hampir sama yaitu sumber (source) berada pada jarak tertentu dari target. Sedangkan radiasi internal yaitu brakhiterapi merupakan penggunaan dari isotop radioaktif Iridium-192 untuk pengobatan, dengan menempatkan bahan radioaktif ke dalam atau berdekatan dengan sasaran radiasi.

\subsection{LINAC (Linear Accelerator)}

Linear Accelerator (LINAC) adalah pesawat pemercepat partikel yang digunakan untuk mematikan sel tumor maupun kanker pada pengobatan dengan radioterapi. Akselerator Linear ini pertama kali diperkenalkan oleh R. Wideroe di Swiss pada 1929 yang pada awalnya digunakan untuk mempercepat partikel ber,muatan posistif seperti proton, namun setelah modifikasi LINAC juga dapat digunakan untuk mempercepat partikel bermuatan negatif seperti elektron.

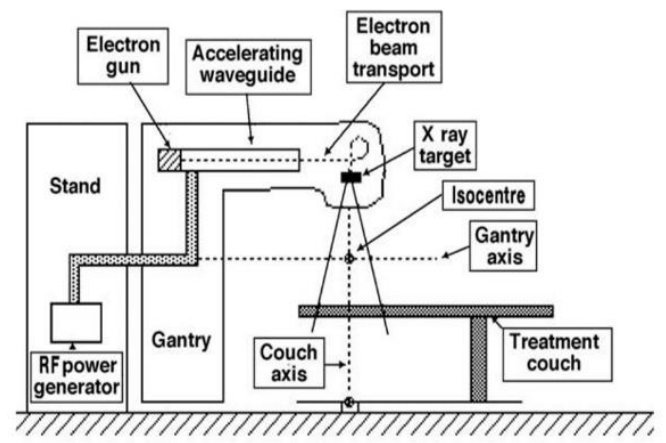

Gambar 2.1. Bagian-bagian LINAC

Prinsip kerja LINAC adalah mempercepat parikel bermuatan sehingga partikel tersebut menghasilkan energi kinetik yang sangat tinggi. Pesawat LINAC menggunakan gelombang elektromagnetik dengan frekuensi tinggi untuk mempercepat partikel bermuatan seperti elektron sehingga menghasilkan energi yang diarahkan pada sebuah tabung linear. Elektron energi tinggi yang dihasilkan dapat digunakan langsung untuk terapi tumor dekat permukaan, atau diarahkan ke suatu target untuk menghasilkan sinar-X Megavolt yang digunakan untuk terapi tumor pada kedalaman tinggi. 


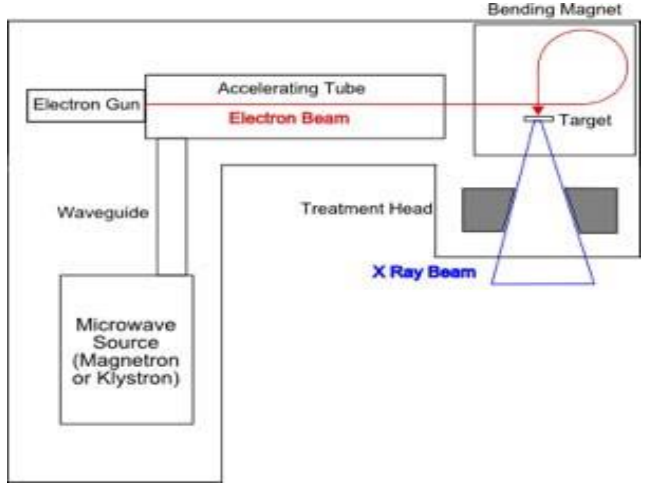

Gambar 2.2. Prinsip kerja LINAC

Mekanisme kerja LINAC ini dimulai dengan sumber gelombang mikro dengan frekuensi tinggi yang dihasilkan oleh magnetron ataupun klystron kemudian gelombang mikro ini digunakan untuk menghasilkan magnet statis yang selanjutnya digunakan untu mempercepat elktron yang dihasilkan elektron gun. Gelombang mikro tersebut akan diperkuat dengan amplifier penguat frekuensi sehingga dihasilkan sebuah sistem pandu gelombang dengan frekuensi mencapai $3 \mathrm{GHz}$. Kemudian pada elektron gun, akan terjadi proses emisi termionik yang mengakibatkan munculnya arus elektron yang disebabkan oleh pemanasan pada filamen tungsten elektron gun. Setelah elektron dihasilkan berkas elektron akan diarahkan ke tabung pemercepat (acceleration tube) untuk dipercepat sehingga energy kitetik akan meningkat. Pada tabung pemercepat ini dilengkapi oleh pengendali arus (drift tube) yang berfungsi membalik polarisasi medan listrik sehingga kecepatan partikel akan bertambah. Kemudian setelah energi kinetnik yang dibutuhkan sudah didaptkan maka berkas elektron tersebut akan diarahkan untuk menumbuk lempengan logam, sehingga akan dihasilkan berkas foton dari proses yang dinamakan Bremstrahlung ini. Oleh karena foton yang dihasilkan tidak menghasilkan berkas foton yang tidak seragam maka dapat digunakan flattening filter (FF) agar dapat diperoleh intensitas energi yang merata. Lalu berkas tersebut akan diarahkan keluar melalui kepala LINAC yang kemudian akan diarahkan mneuju target dengan modifiksi geometri berkas dapat digunkan kolimator sehingga berkas yang keluar sesuai yang diinginkan.

\subsection{Jaminan Kualitas Pada Radioterapi}

Quality Assurance (QA) atau jaminan mutu pada fasilitas radiologi adalah suatu program/langkah teratur yang bertujuan untuk menjamin konsistensi tahapan medik: pemenuhan keamanan dalam pemberian dosis untuk volume organ target tersebut dan dosis seminimal mungkin untuk jaringan normal dan papar pada personil serta pemonitoran yang cukup pada pasien setelah tindakan dengan pertimbangan biaya rendah dan dosis penyinaran terhadap pasien yang serendah rendahnya. Quality Control (QC) atau kontrol mutu adalah suatu tindakan pengukuran yang rutin dilakukan untuk memonitor performa visual dan uji kinerja dari peralatan sehingga kualitas outputnya dapat dijamin. Salah satu rangkaian QA dan QC yaitu kalibrasi (calibration) atau pengukuran. Kalibrasi meliputi kalibrasi harian (daily calibration), kalibrasi mingguan (weekly calibration), dan kalibrasi bulanan (monthly calibration). Kalibrasi sangat penting dilakukan guna memastikan bahwa perangkat yang digunakan, dalam kasus ini Linac, masih sesuai standar dan tidak berbahaya bagi pasien.

Jaminan kualitas pada radioterapi adalah semua prosedur yang dapat menjamin konsistensi tahapan medik, yaitu : pemenuhan keamanan dalam pemberian dosis untuk volume organ target tersebut, dan dosis seminimal mungkin untuk jaringan normal dan paparan pada personil serta pemonitoran yang cukup pada pasien setelah tindakan. Untuk membuktikan adanya jaminan kualitas perlu penilaian kualitas (quality assessment) dan kontrol kualitas (quality control). Penilaian kualitas adalah kegiatan yang dilaksanakan untuk mengukur atau mengevaluasi kinerja proses radioterapi. Sedangkan kontrol kualitas adalah ukuran yang diambil untuk menilai, merawat atau memperbaiki kualitas perlakuan. Dari kuesioner yang diberikan WHO kepada 56 institusi dari 52 negara didapat jawaban bahwa Program Jaminan Kualitas pada radioterapi perlu dilakukan untuk:

1. Meminimalkan kesalahan dalam perencanaan perlakuan dan pemberian dosis pada pasien serta memperbaiki hasil terapi dan mengurangi komplikasi serta kekambuhan

2. Sebagai ajang interkompararasi radioterapi, baik nasional, regional dan internasional

3. Mengeksploitasi kinerja peralatan radioterapi modern. Hal ini dapat tercapai bila derajat akurasi tinggi dan konsistensi tercapai.

4. Meningkatkan aplikasi radioterapi di negara berkembang.

\section{METODE PENELITIAN}

Metode penelitian yang dilakukan diantaranya orientasi, observasi, pengerjaan penelitian, konsultasi dan diskusi, penyusunan, serta penyerahan hasil penelitian.

Orientasi dilakukan dengan mempelajari dan mengenali tempat penelitian. Kemudian dilakukan observasi terkait penelitian yang akan dilakukan sehingga pengerjaan penelitian dapat dilakukan dengan maksimal. Kemudian sesi konsultasi dengan dosen pembimbing dan diskusi antar rekan penelitian. Penyusunan laporan 
penelitian pun dapat mulai dikerjakan untuk diserahkan sebelum tenggat waktu yang telah ditentukan.

\section{HASIL DAN PEMBAHASAN}

QA/QC merupakan suatu kegiatan yang digunakan untuk menjaga kondisi perangkat agar dapat selalu berfungsi dengan baik. Pihak yang berperan dalam menentukan jaminan mutu alat atau QA/QC ini adalah fisikawan medis yang dalam pelaksanaannya biasa dibantu oleh radiografer. Pada Instalasi Radioterapi RSUD Dr. Soetomo untuk QA/QC alat radioterapi LINAC dengan merk Varian ini dilakukan tiga macam test yaitu daily test, monthly test dan annual test.

\subsection{Daily test (Kontrol harian)}

Jaminan kualitas harian dilakukan pada semua alat yang diperlukan dalam kegiatan terapi karena semua alat harus dalam keadaan baik dan layak sebelum digunakan untuk terapi pasien. Daily test atau kontrol kualitas harian pada LINAC ini dilakukan karena adanya ketidakstabilan berkas terhadap waktu. Hal ini sangat penting untuk dilakukan karena pada terapi radiasi ketepatan dan ketelitian dosis yang diberikan pada pasien akan sangat mempengaruhi efektivitas pengobatan atau perlakuan terapi. Beberapa hal yang dilakukan pada pesawat LINAC 2300IX dan LINAC 600CD di Instalasi Radioterapi RSUD Dr. Soetomo untuk jaminan kualitas harian yaitu dilakukan pengecekan pada laser, isocenter, collimator rotation, door interlock, emergency stop, kunci pintu ruang LINAC serta Radiation Room Monitor dan Audio Visual Contact.

Dalam pengecekan haria ini laser yang digunakan adalah laser merah dengan panjang gelombang $\pm 635 \mathrm{~nm}$ dengan akurasi penyesuaian pada isocenter $\pm 0,5 \mathrm{~mm}$ dimana keterangan batastoleransi yaitu sebesar $2 \mathrm{~mm}$ maka laser dikatakan berfungsi dengan baik. Kemudian pengecekan isocenter yang dilakukan menggunakan kertas millimeter blok sebagai pengganti target atau luas lapangan radiasi $10 \mathrm{~cm}$ x $10 \mathrm{~cm}$ dengan mengatur posisi meja pasien secara vertikal, horizontal maupun longitudinal sampai bidang cahaya pada kolimator memenuhi luas bidang pada kertas. Pengecekan collimator rotation yang dilakukan untuk mengetahui kesesuaian pengaturan bacaan luas lapangan pada kolimator dengan bacaan sesungguhnya dimana perubahan sudut kolimator tdak mempengaruhi isocenter. Selanjutnya pengecekan pada door interlock, kunci pintu ruang LINAC, emergency stop serta Radiation Room Monitor dan Audio Visual Contact yang mana dalam pengecekan ini semua alat harus berfungsi dengan baik karena pada komponen-komponen ini merupakan perangkat keamanan dalam proses terapi radiasi, yang apabila terdapat salah satu dari komponen tersebut rusak maka fisikawan medis harus segera menghubungi pihak teknisi agar dapat segera diperbaiki sehingga pesawat LINAC bias beroperasi kembali.

Secara umum daily test berdasarkan AAPM TG-40 seperti tabel dibawah ini:

Tabel 4.1. Daily test LINAC

\begin{tabular}{|lll|}
\hline Frequency & \multicolumn{1}{c}{ Procedure } & \multicolumn{1}{c|}{ Action level $^{\mathrm{a}}$} \\
\hline Daily & X ray output constancy & $3 \%$ \\
& Electron output constancy & $3 \%$ \\
& Lasers & $2 \mathrm{~mm}$ \\
& Distance indicator & $2 \mathrm{~mm}$ \\
& Door interlock & Functional \\
& Audiovisual monitor & Functional \\
\hline
\end{tabular}

Pada Tabel 4.1 dijelaskan bahwa untuk kolom Action levela diisi dengan parameter tindakan atau toleransi yang jika terdapat ketidak sesuaian maka harus dilakukan tindakan. Sedangkan untuk constancyb disini yaitu semua energi elektron tidak perlu diperiksa setiap hari, tetapi semua energi elektron harus diperiksa setidaknya dua kali seminggu.

\subsection{Monthly test}

Pada uji jaminan mutu bulanan ini biasanya dilakukan measurement (pengukuran) untuk mengukur dosis keluaran LINAC setiap hari, yang kemudian hasil pengukuran tersebut akan dibandingkan degan dosis masukan LINAC yang dilakukan dengan menggunakan Water Phantom atau Slab Phantom (Solid Phantom). Seperangkat alat water phantom akan mendeteksi berupa keluaran dosis dari pesawat LINAC yang ditampilkan melalui elektrometer dengan satuan MU (Monitor Unit). Keluaran dari water Phantom akan menunjukkan keluaran dari pesawat LINAC selama digunakan dengan mengacu pada nilai $1 \mathrm{cGy}$ setara dengan $1 \mathrm{MU}$. Tujuan dari monthly test atau pengecekan bulanan ini adalah untuk kalibrasi alat yaitu proses pengecekan dan pengaturan akurasi alat serta

konsistensi alat dengan membandingkan hasil terhadap suatu standar. Pada dasarnya kalibrasi dilakukan untuk mengatur ulang fungsi alat agar kembali berfungsi seperti semula. Kedua pengukuran tersebut dilakukan sesuai dengan protokol IAEA TRS-398. Hasil dari perhitngan dosis tersebut merupakan hasil kalibrasi alat yang menunjukkan bahwa dosis keluaran LINAC sama dengan dosis yang ditentukan. 
Secara umum monthly test pada LINAC berdasarkan AAPM TG-40 adalah seperti pada Tabel 4.2 berikut:

Tabel 4.2. Monthly test LINAC

\begin{tabular}{|c|c|c|}
\hline Frequency & Procedure & Action level ${ }^{\mathrm{a}}$ \\
\hline Monthly & $\begin{array}{l}\text { X ray output constancy }{ }^{\mathrm{e}} \\
\text { Electron output constancy }^{\mathrm{e}} \\
\text { Backup monitor constancy } \\
\text { X ray central axis dosimetry parameter } \\
\text { constancy (PDD, TAR, TPR) } \\
\text { Electron central axis dosimetry } \\
\text { parameter constancy (PDD) } \\
\text { X ray beam flatness constancy } \\
\text { Electron beam flatness constancy } \\
\text { X ray and electron symmetry } \\
\text { Emergency off switches } \\
\text { Wedge and electron cone interlocks } \\
\text { Light/radiation field coincidence } \\
\text { Gantry/collimator angle indicators } \\
\text { Wedge position }\end{array}$ & $\begin{array}{l}2 \% \\
2 \% \\
2 \% \\
2 \% \\
2 \mathrm{~mm} \text { at therapeutic } \\
\text { depth } \\
2 \% \\
3 \% \\
3 \% \\
\text { Functional } \\
\text { Functional } \\
2 \mathrm{~mm} \text { or } 1 \% \text { on a side } \\
1^{\circ} \\
2 \mathrm{~mm} \text { (or } 2 \% \text { change } \\
\text { in transmission } \\
\text { factor) } \\
2 \mathrm{~mm} \\
2 \mathrm{~mm} \\
2 \mathrm{~mm} \text { diameter } \\
2 \mathrm{~mm} / 1^{\circ} \\
\text { Functional } \\
2 \mathrm{~mm} \\
\text { Functional }\end{array}$ \\
\hline
\end{tabular}

Pada Tabel 4.2. dijelaskan bahwa untuk kolom Action level ${ }^{\mathrm{a}}$ diisi dengan parameter tindakan atau toleransi yang jika terdapat ketidak sesuaian maka harus dilakukan tindakan. Kemudian yang dimaksud dengan constancy ${ }^{\mathrm{c}}$ yaitu pemeriksaan ketetapan dengan sebuah field instrument menggunakan koreksi suhu dan tekanan. Lalu on a sided disini diartikan dengan mana yang lebih besar, juga yang harus diperiksa setelah perubahan sumber bidang cahaya. Jaw symmetrye dimaksudkan dengan simetri rahang yang didefinisikan sebagai perbedaan jarak masing-masing rahang dari isocenter.

Pada Instalasi Radioterapi RSUD Dr. Soetomo biasanya dilakukan pengukuran dengan Slab Phantom 1-2 kali dalam seminggu tergantung banyaknya pasien yang melakukan penyinaran. Sedangkan untuk pengukuran dengan Water Phantom dilakukan satu kali dalam sebulan. Prosedur dari masing-masing kalibrasi dijelaskan pada Tabel 4.3. dan Tabel 4.4. Hal ini dilakukan dengan tujuan untuk menjaga kualitas dosis keluaran LINAC yang diterima pasien sebagai efektifitas pengobatan serta menjamin mutu alat dari segi penggunaan serta keamanan alat bagi pasien maupun petugas dan lingkungan sekitar

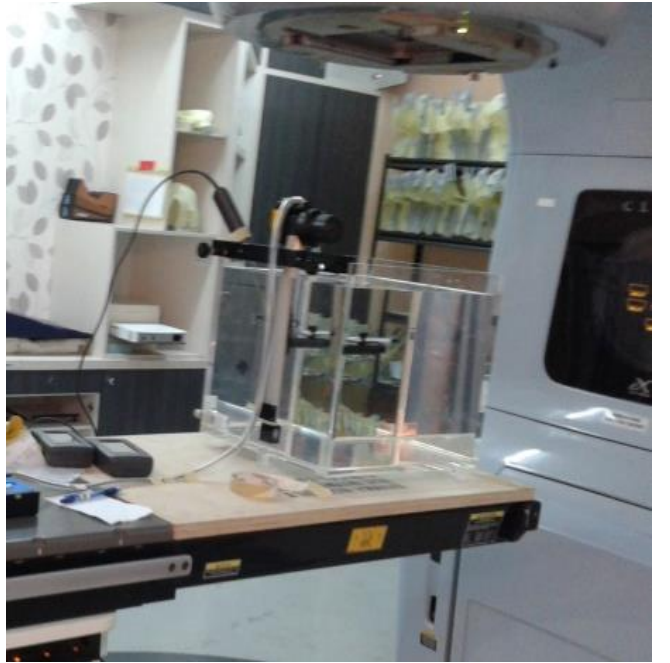

Gambar 3. Set up kalibrasi water phantom

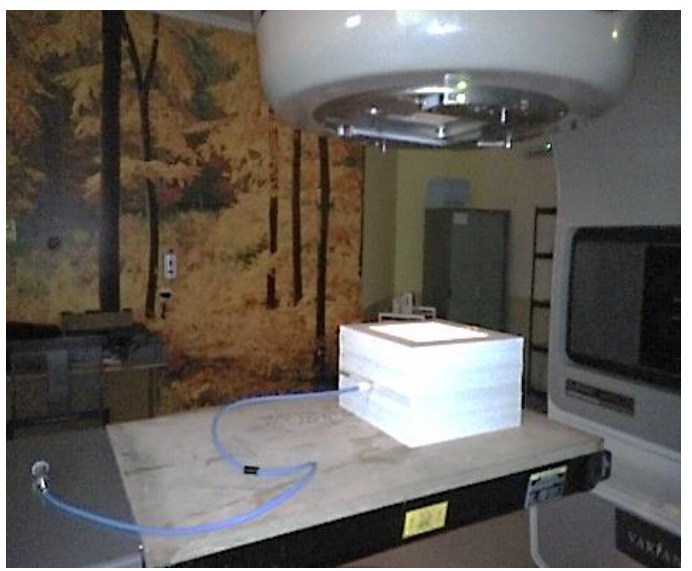

Gambar 4. Set up kalibrasi slab phantom

Tabel 4.3. Prosedur kalibrasi LINAC menggunakan Water Phantom di Instalasi Radioterapi RSUD Dr Soetomo

\begin{tabular}{|l|l|}
\hline No. & Prosedur Water Phantom \\
\hline 1. & $\begin{array}{l}\text { Medium yang digunakan adalah } \\
\text { aquades }\end{array}$ \\
\hline 2. & $\begin{array}{l}\text { Meja pasien yang akan digunakan } \\
\text { untuk pengukuran diganti terlebih } \\
\text { dahulu dengan meja kalibrasi. }\end{array}$ \\
\hline 3. & $\begin{array}{l}\text { Posisikan phantom yang akan } \\
\text { digunakan dalam keadaan seimbang } \\
\text { dengan bantuan waterpass. }\end{array}$ \\
\hline 4. & $\begin{array}{l}\text { Kemudian aquades dimasukkan } \\
\text { kedalam phantom sebanyak } 3 / 4 \text { bagian } \\
\text { wadah. }\end{array}$ \\
\hline 5. & $\begin{array}{l}\text { Pasang alat pengukur tekanan dalam } \\
\text { air phantom. }\end{array}$ \\
\hline 6. & $\begin{array}{l}\text { Pastikan SSD 100 cm dengan luas } \\
\text { lapangan 10 x 10 cm } 2\end{array}$ \\
\hline 7. & $\begin{array}{l}\text { Laser dinyalakan dan diatur rotasi } \\
\text { kolimatornya. }\end{array}$ \\
\hline 8. & Pastikan gantry pada posisi 0 derajat. \\
\hline 9. & $\begin{array}{l}\text { Kemudian catat suhu, tekanan } \\
\text { lingkungan dan kelembaban ruangan } \\
\text { sebagai faktor koreksi. }\end{array}$ \\
\hline
\end{tabular}




\begin{tabular}{|c|l|}
\hline 10. & $\begin{array}{l}\text { Pasang detector ion chamber pada } \\
\text { fiksasi, kemudian pastikan posisi } \\
\text { detektor lurus dan sejajar }\end{array}$ \\
\hline 11. & $\begin{array}{l}\text { Pastikan posisi detector berada pada } \\
\text { kedalaman } 10 \text { cm dibawah permukaan } \\
\text { air dan pastikan lurus dengan } \\
\text { kolimator. }\end{array}$ \\
\hline 12. & $\begin{array}{l}\text { Kemudian hubungkan detector ion } \\
\text { chamber pada elektrometer. }\end{array}$ \\
\hline 13. & $\begin{array}{l}\text { Lalu keluar ruangan, dan Linac } \\
\text { dipanaskan dengan MU 100, energy }= \\
\text { 6MV. }\end{array}$ \\
\hline 14. & $\begin{array}{l}\text { Catat bacaan muatan saat }-300 \mathrm{~V},- \\
\text { 100 V dan +300V. }\end{array}$ \\
\hline 15 & $\begin{array}{l}\text { Kemudian olah data pengukuran } \\
\text { terebut dengan aplikasi TRS. }\end{array}$ \\
\hline
\end{tabular}

Tabel 4.4. Prosedur kalibrasi LINAC menggunakan Solid Phantom di Instalasi Radioterapi RSUD Dr Soetomo

\begin{tabular}{|l|l|}
\hline No. & $\begin{array}{l}\text { Prosedur Solid Phantom (Slab } \\
\text { Phantom) }\end{array}$ \\
\hline 1. & $\begin{array}{l}\text { Slab/phantom yang digunakan } \\
\text { memiliki ketebalan 1 ml atau 1/2 ml }\end{array}$ \\
\hline 2. & $\begin{array}{l}\text { Susun slab/phantom dengan urutan 5 } \\
\text { tumpukan slab pada bagian bawah, } \\
\text { pada bagian tengah diberi slab dengan } \\
\text { lubang dan 10 tumpukkan slab pada } \\
\text { bagian atas. }\end{array}$ \\
\hline 3. & $\begin{array}{l}\text { Atur laser dan kolimator, kemudian } \\
\text { pasang detector pada slab yang } \\
\text { berlubang. }\end{array}$ \\
\hline 4. & $\begin{array}{l}\text { Pastikan ketika kalibrasi gantry dalam } \\
\text { posisi 0 dan SAD 100 cm }\end{array}$ \\
\hline 5. & $\begin{array}{l}\text { Kemudian proses kalibrasi dijalankan, } \\
\text { LINAC dipanaskan (personil/petugas } \\
\text { keluar ruangan, dan kalibrasi dilakukan } \\
\text { melaui ruang operator) }\end{array}$ \\
\hline 6. & $\begin{array}{l}\text { Kalibrasi dilakukan dengan batas -300 } \\
\text { V, -100 V dan +300 V dan diulangi } \\
\text { sebanyak 3 kali. }\end{array}$ \\
\hline
\end{tabular}

\subsection{Annual test}

Annual test atau pengecekan tahunan ini merupakan uji alat dengan membandingkan hasil pengukuran dosis pengeluaran yang telah dilakukan selama setahun untuk mengetahui konsistensi alat. Pihak yang berparan dalam kegiatan annual test ini adalah fisikawan medis yang dibantu oleh radiografer. Annual test biasanya juga dilakukan bersama dengan pihak BAPETEN/BATAN sebagai pengecekan tahunan LINAC pada setiap rumah sakit serta sebagai pengecekan kualitas atau mutu rumah sakit dalam penggunaan alat radioterapi.
Sehingga dapat dilihat kualitas setiap rumah sakit dalam pelayanan radioterapi.

Jaminan kualitas tahunan perlu dilakukan setiap tahun. Salah satu parameter penting yang perlu diperiksa yaitu keluaran dosis pesawat LINAC. Dosis keluaran pesawat LINAC yang telah diukur dengan menggunakan Water Phantom setiap bulan akan dilihat stabilitasnya. Jika stabilitas terjaga dengan baik, maka alat pesawat LINAC masih bekerja dengan baik. Apabila diketahui keluaran dosis Pesawat LINAC tidak lagi stabil, maka seorang fisikawan medis harus melaporkan kesalahan tersebut kepada seorang teknisi alat pesawat LINAC sehingga dapat diperbaiki dan dapat bekerja dengan baik.

Secara umum annual test pada LINAC berdasarkan AAPM TG-40 adalah seperti pada Tabel 4.5. yang dalam tabel tersebut dijelaskan bahwa bahwa pada kolom Action level ${ }^{\text {a }}$, dapat diisi dengan parameter dan akan dilakukan tindakan apabila kurang sesuai parameternya. Kemudian untuk constancy ${ }^{\mathrm{f}}$ disini dimaksutkan sebagian besar factor transmisi baji bergantung pada ukuran bidang dan kedalaman. Khususnya variasi ukuran bidang untuk irisan dinamis bisa sangat besar

Tabel 4.5. Annual test LINAC

\begin{tabular}{|lll|}
\hline Frequency & \multicolumn{1}{c|}{ Procedure } & Action level $^{\mathrm{a}}$ \\
\hline Annually & X ray/electron output calibration constancy & $2 \%$ \\
& Field size dependence of X ray output constancy & $2 \%$ \\
& Output factor constancy for electron applicators & $2 \%$ \\
& Central axis parameter constancy & \\
& (PDD, TAR, TPR) & $2 \%$ \\
& Off-axis factor constancy & $2 \%$ \\
Transmission factor constancy for all treatment & & $2 \%$ \\
accessories & $2 \%$ \\
Wedge transmission factor constancy & $1 \%$ \\
Monitor chamber linearity & $2 \%$ \\
X ray output constancy with the gantry angle & $2 \%$ \\
Electron output constancy with the gantry angle & $2 \%$ \\
Off-axis factor constancy with the gantry angle & $2 \%$ \\
Arc mode & Manufacturer's \\
Safety interlocks: follow manufacturer's & specifications \\
test procedures & Functional \\
Collimator rotation isocentre & $2 \mathrm{~mm}$ diameter \\
Gantry rotation isocentre & $2 \mathrm{~mm}$ diameter \\
Table rotation isocentre & $2 \mathrm{~mm}$ diameter \\
Coincidence of collimator, gantry and table & $2 \mathrm{~mm}$ diameter \\
axes with the isocentre & \\
Coincidence of the radiation and mechanical & $2 \mathrm{~mm}$ diameter \\
isocentre & $2 \mathrm{~mm}$ \\
Table top sag & $2 \mathrm{~mm}$ \\
Vertical travel of the table & \\
\hline
\end{tabular}

\section{KESIMPULAN DAN SARAN}

QA/QC pesawat LINAC merupakan serangkaian program yang dilakukan untuk menjamin kualitas dan konsistensi dosis keluaran LINAC. QA/QC LINAC dilakukan dengan tiga test yaitu daily test, monthly test dan annual test. Daily test merupakan pengecekan harian yang dilakukan pada semua komponen radioterapi LINAC mulai dari komponen LINAC hingga system keamanan ruang LINAC seperti pengecekan laser, isocenter, 
collimator rotation, door interlock, emergency stop, kunci pintu ruang LINAC, audio visual monitor dan radiation room monitor. Monthly test adalah pengecekan bulanan berupa kalibrasi alat dengan melakukan pengukuran menggunakan Water Phantom atau Slab Phantom. Annual test yaitu pengecekan tahunan yang dilakukan untuk mengontrol stabilitas dosis keluaran yang telah diukur setiap bulan selama setahun. Jika stabilitas terjaga dengan baik, maka alat pesawat LINAC masih bekerja dengan baik. Apabila diketahui keluaran dosis Pesawat LINAC tidak lagi stabil, maka seorang fisikawan medis harus melaporkan kesalahan tersebut kepada seorang teknisi alat Pesawat LINAC sehingga dapat diperbaiki dan dapat bekerja dengan baik.

\section{UCAPAN TERIMA KASIH}

Penulis mengucapkan terima kasih kepada dr. Dyah Erawati, Sp.Rad (K) Onk.Rad selaku Kepala Instalasi Radioterapi, M. Rizqi Aditya Rahman, S.Si, Wulandhari, S.Si yang juga telah membimbing pengambilan data di Rumah Sakit Dr Sutomo

\section{DAFTAR PUSTAKA}

Akhadi, Mukhlis. 2000. Dasar-Dasar Proteksi Radiasi. Jakarta: Rineka Cipta.

Amalia T dan Kurniawan B. 2004. "Analisa Profil Berkas Elektron Pesawat Akselerator Linear Medik." dalam Jurnal Departemen Fisika MIPA. Jakarta : Universitas Indonesia

Anies. 2006. "Potensi Gangguan Kesehatan Akibat Radiasi Elektromagnetik SUTET". Jakarta : Kelompok Gramedia.

Arismunandar dan Silakhuddin. 2000. "Struktur dan Segi-segi Keselamatan Linac Medik" dalam Pusat Pengembangan Sistem ReaktorMaju. BATAN. ISSN:08542910.

Asrisal R, Dewang S dan Tahir D. 2013. "Verivikasi Berkas Elektron Pesawat Linear Acceleration (LINAC) dengan Variasi Energi pada Water Phantom" . Jurusan Fisika Fakultas MIPA : Universitas Hasanuddin.

Brown .B.H, R H Smallwood, dkk.1999.Medical Physics And Biomedical Engineering. Institute of Physics Publishing Bristol and Philadelphia. ISBN:07503-0368-9
Chember H. 1983. Pengantar Fisika Kesehatan (Terjemahan Achmad Toekiman) edisi kedua. Semarang : IKIP

Christofides S, D.R. Dance, 2014. Diagnostic Radiology Physics: A Handbook for Teachers and Students.Vienna : IAEA

Dharmawati dan Suharni. 2012. "Implementasi Linear Accelaration dalam penanganan kasus kanker" dalam Prosiding PPI Teknologi Akselator dan Aplikasinya Volume 14 (hlm. 36-47).

Direktorat Perizinan Fasilitas Radiasi dan Zat Radioaktif BAPETEN. 2019.Buku

Panduan Perizinan Radioterapi.Jakarta: BAPETEN

Djuita F, Rina T dan Andreas N.2011, "Kontrol Kualitas Terapi Radiasi Pada Unit Radioterapi" dalam Prosiding Seminar Keselamatan Nuklir

Setiawan H dan Rena W.2016. "Analisis Dosis Keluaran Berkas Foton dan Elektron Energi Tinggi Pesawat Linac Elekta Precise 5991 Berdasarkan Code of Practice IAEA TRS 398" dalam Prosiding SKF. ISBN: 978-60261045-1-9

Khan, Faiz M. 1994. The Physics of Radiation Therapy. 2th Edition. Williams \& Wilkins : Sydney.

Metcalfe P, Kron T dan Hoban.P. 2007. "The Physics of Radioteraphy X-ray and Electron" dalam Medical Physics Publishing. Madison : Wisconsin

Fitriatuzzakiyah N, Rano K dan Irma M. 2017. "Terapi Kanker dengan Radiasi: Konsep Dasar Radioterapi dan Perkembangannya di Indonesia" dalam Jurnal Farmasi Klinik Indonesia Volume 6 No. 4 (hlm 311-320).

Peraturan Kepala Badan Pengawas Tenaga Nuklir Nomor 3 Tahun 2013 tentang Keselamatan Radiasi dalam Penggunaaan Radioterapi . BATAN.

Podgorsak, E.B. 2005. Radiation Oncology Physics: A Handbook For Teachers And Students.Vienna : IAEA

Podgorsak, E.B.2010. Radiation Physics for Medical Physicists.2th Edition. SpringerVerlag Berlin Heidelberg :New York

Smith K, Peter Balter,dkk.2017. "AAPM Medical Physics Practice Guideline 8.a.: Linear accelerator performance tests" dalam Journal of Applied Clinical Medical Physics Vol 18 No. 4 (page 23-39) 
Suhartono, Z. 1990. Dosimetri Radiotherapy.

Jakarta: PSPKR-BATAN. 